Urban Design International (2014).

\title{
Space, movement, and heritage planning of the historic cities in Islamic societies: Learning from the Old City of Jeddah, Saudi Arabia
}

Mahbub Rashid* and Ahmed Ali A Bindajam

School of Architecture, Design, \& Planning, University of Kansas, 1465 Jayhawk Boulevard, Lawrence, Kansas 66045, USA.

E-mail: mrashid@ku.edu

\begin{abstract}
Traditional historic cities in Islamic societies of Asia and Africa are fast disappearing and/or losing relevance. There is a clear need for heritage planners to plan for what is left and to integrate these historic cities with the bigger cities that surround them. This study on movement dynamics of people and cars in relation to spatial configuration, described using space syntax, was undertaken in the Old City of Jeddah to understand and learn how accessibility and the density of people and activities can be used for retaining the viability and vitality of this and other historic cities. The study reports several findings that are potentially relevant to heritage planning. However, further studies are needed to understand the importance of the findings in relation to different social and symbolic realities of Islamic societies before specific spatial strategies can be identified for heritage planning in this and other historic cities.

Key words: Heritage planning; Traditional historic cities; Islamic societies; Space; Movement; Space syntax; Jeddah
\end{abstract}




\section{Space, movement, and heritage planning of the historic cities in Islamic societies: Learning from the Old City of Jeddah, Saudi Arabia}

\section{INTRODUCTION}

\section{The problem of managing historic cities in Islamic societies}

Many important cities of the premodern era flourished in Islamic societies of Asia and Africa. The forces and agents that shaped the traditional institutions and structures of these cities (for a discussion, see Abu-Lughod, 1993; Zubaida, 1989) also produced such visible spatial complexes as the mosque-madrassa complexes, autonomous neighborhoods (also known as haras or mahallas), the bazaars (also known as suqs), semiprivate transitional spaces, and introverted houses. Together, they shaped the experience of urbanity in these historic cities. However, under the European influences many of these cities experienced significant changes during the last hundred years or so (Amirahmadi \& Razavi, 1993). These changes, involving physical, social, cultural, and economic dimensions, now threaten the identity and/or vitality of these historic cities. The physical structure, although still attractive in many cases, is now being replaced, modernized and/or refurbished to accommodate new functions; thus, undermining the experience of traditional urbanity. How to deal with these changes of the historic cities in Islamic societies, therefore, is a major concern for all those interested in preserving urban heritage and identity.

Heritage planning of living historic cities, like the ones in Islamic societies, must be considered carefully. They often do not represent the conditions that gave rise to the traditional urban conservation and preservation approaches. The foundations of these traditional approaches were 
formed in the early nineteenth century in the Western European World, where rapid changes in cities due to industrialization created a feeling of dissatisfaction and disassociation. As a result, a strong desire or need to experience an 'authentic' past, different and distant from the present, had developed (Lowenthal, 1995). This emphasis on a discontinuity between the present and the past still is a part of such more modern practices as those included in the Athens and Venice Charters (League of Nations, 1931; ICOMOS, 1964); and are often transferred to, or even imposed on, many other parts of the world, where in most cases the past is still very much alive in the present (Byrne, 1991). One consequence of a focus on discontinuity is that it generally disregards the fact that living historic cities, like all other cities, are complexes of forms and functions in continuous interaction; and without such interaction, these cities reduce to historic theme parks. [Ashworth, 1993; see Poulios (2010) for additional discussion on the topic.]

Today, the heritage planning of living historic cities has become important as the number of designated urban World Heritage Sites (WHSs) has proliferated across the world over the last two decades (Pendlebury, et al. 2009). To emphasize a need to see urban WHSs as first and foremost places where people live, the Vienna Memorandum (UNESCO, 2005) focused on several principles including the concept of historic landscape and the importance of understanding place. Some of the elements incorporated in these concepts are cityscape, urban morphology, functionality, authenticity and integrity, genius loci and intangible values (Alberts and Hazen, 2010; Pendlebury, et al. 2009; Rodwell, 2007, 2008). Though these concepts and terms are rarely precise and rigorous, it is clear that, a heritage city, if identified, must exist as an integral part of the multifunctional city. It must make use of such urban attributes as the atmosphere of historicity, accessibility, and the density of people and activities to not only meet any conservation objectives but also to create appropriate economic opportunities for retaining 
the viability and vitality of the heritage city (Ashworth, 1993; Ford, 1985; Baer, 1995). It is in this regard, the lack of an appreciation for the importance of space and movement or place and flow in the literature on the heritage planning of historic cities is remarkable.

\section{Space and movement in relation to heritage planning}

The importance of space and movement in cities is well recognized in many disciplines including sociology (Goffman, 1963, 1972; Lefebvre, 1991), geography (Christaller, 1933; Ullman, 1954; Weber, 1921) and architecture and urban studies (Jacobs, 1961; Hillier, 1996). For example, in his urban sociological studies, Goffman (1972) looked at movement or flow to uncover the meaning of social interaction and cultural production in a general sense. He referred to mobility as an aspect of urbanity in a number of examples and empirical discussions. Goffman also developed a rich vocabulary for describing mobility in urban life impacting the way we think about self and other, place and space in cities. Therefore, it can easily be argued that for Goffman urban mobility was more than movement from A to B. Rather, it is one of the basic building blocks of the social fabric of the city. By moving in the city among buildings, objects, and people, one interacts with the "environment," making sense of it and ultimately producing culture and identity (Jensen, 2010).

In geography, the relationship between places and flows has been the subject of study for decades. The classical function of the city as a center of movement and exchange was acknowledged in traditional urban theories. For example, Weber (1921, trans. 1968) argued that the regular exchange of goods was one of the basic characteristics of cities. Christaller (1933, trans. 1966) used the central place theory to explain the size, significance and spatial distribution of cities or settlements against the background of the management of flows. In his contribution 
on 'geography as spatial interaction', Edward Ullman (1954, reprint. 1980) explained how flows and physical space interact stressing the basic role of the interplay of site and situation. His view evolved from a critical assessment of the discipline as being obsessed by the gravity model and its emphasis on areas and territories, rather than on behavior, situation and interrelation. More recently, the relationship between places and flows has altered due to extraordinary technological and socio-economic changes. As a result, some have argued for the primacy of 'the space of flows' over 'the space of places' (e.g., Castells, 2002). Others have dissented suggesting neither that places dominate flows nor that flows tend to determine places. The two are intertwined in a complex relationship that is constantly reproduced (e.g., Hesse, 2010).

In architecture and urban design, Jane Jacobs (1961) discussed forcefully the role of movement in relation to urbanity. Street safety, she suggested, is promoted by spontaneous protection with the eyes of both pedestrians and those watching the continual flow of pedestrians from buildings. She also suggested 'a dense concentration of people' as a precondition of lively cities. After Jacobs, many other people have taken a similar view arguing that successful urban places are based predominantly on the various ways in which street life occurs (for example, see Buchanan, 1988; Cook, 1980; Gehl, 1989; Montgomery, 1998).

More recently, Hillier (1996) discusses the relationship between space and movement in cities. Unlike Jacobs, Hillier identifies multifunctionality and the part-whole structure as the two most important issues of urbanity. Both of which, according to Hillier, relies on spatial configuration determining how we as individuals find the city intelligible, and how we move around it. Based on the findings of the empirical studies that he and others have conducted around the world using space syntax, the theories and methods that he pioneered, Hillier writes, 
[The] structure of the urban grid considered purely as a spatial configuration, is itself the most powerful single determinant of urban movement, both pedestrian and vehicular. Because this relation is fundamental and lawful, it has already been a powerful force in shaping our historically evolved cities, by its effect on land-use patterns, building densities, the mixing of uses in urban areas and the part-whole structure of the city. (Hillier, 1996:113)

If movement and its relationships with space are important for cities in general, as argued by many, then these must be even more important for living historic cities. While movements of people and cars on the streets of these cities may be good indicators for liveliness and vitality, high-density movements that defy the traditional social logic of space can easily damage the physical and social environments of these cities forcing traditional dwellers of these historic cities to move somewhere else. As they move out, the building they leave behind are taken over by commercial functions, poor people, or by people with little knowledge of the traditional ways of these cities.

When the traditional functions of historic cities are taken over by commercial functions, property values and rents rise. They bring in new economically stronger business establishments, such as banks, supermarket, luxury shops and large hotel chains, that push out economically weaker shops and crafts as well as social and cultural institutions. They also bring in more cars. As a result, the processes of destruction, modernization and/or refurbishment of historic buildings are enhanced, which cause the camaraderie of these cities to change.

In contrast, when taken over by poor people, the transformation of historic cities is slow but often towards self-destruction. For a lack of proper maintenance, the fragile buildings and fabric 
of these cities become even more fragile, ruinous and unusable. The more dilapidated these cities are, the more they bring in poor people. Soon, they become slums with overcrowding and crimes where no one wants to invest making it difficult to preserve and maintain the heritage of historic cities.

Given the importance of movements of people and cars for street life and urbanity as sketched above, this paper takes the view that learning and understanding spatial configuration and its effects of movement of people and vehicles in historic cities can be important for the heritage planning of these cities. Therefore, in the next few sections the paper presents a study that was undertaken to understand space, movement, and their relationships in the Old City of Jeddah in Saudi Arabia. The aim of the study was to uncover spatial patterns of movement that could be encouraged, discouraged and/or maintained in the process of heritage planning of this historic city.

The paper is organized as follows: First, a description of the Old City of Jeddah is provided explaining why and how movements of people and cars can be important for its heritage planning. Second, the methodology of the study is discussed. The discussion includes the techniques of field observation of movements of people and cars, the techniques of the analysis of spatial configuration, and the techniques of statistical analysis establishing the relationships between space and movement. Third, the findings of field observation, configurational analysis, and statistical analysis are discussed. Finally, the significance and limitations of the study are discussed in relation to the Old City of Jeddah in particular, and in relation to the other historic cities in Islamic societies in general. 


\section{THE CASE OF THE OLD CITY OF JEDDAH, SAUDI ARABIA}

The City of Jeddah, with its Old City (Al Balad) at the center, is located on the coast of the Red Sea in the Kingdom of Saudi Arabia (Figures 1 \& 2). This Old City is considered one of the most important areas in the city. It was and is the commercial hub of the city and the western region of the Kingdom. Though the Old City of Jeddah had existed before Islam, it gained importance in 647 A.D. when the third Muslim Caliph, Uthman Ibn Affan, turned it into a port for Muslim pilgrims making the required Hajj to Mecca (http://en.wikipedia.org/wiki/Jeddah). Today, the Old City of Jeddah still contains its traditional urban fabric along with many historic landmarks and mosques, old neighborhoods or Harahs, old paths and bazaars or Souks; thus, providing a genuine living example of a historic city in Islamic societies (Figure 2). Given its historical importance and rich architectural and urban heritage, the Government of Saudi Arabia has included the Old City of Jeddah as one of two properties in its tentative list of properties to be considered for the WHS status. (http://whc.unesco.org/en/tentativelists/5085/)

As the 1938 photographs in Figures 3 \& 4 show, the Old City of Jeddah changed very little until the mid-twentieth century. It was only after the demolition of the Old City Wall in 1947 A.D. that urban redevelopment projects started to significantly change the Old City of Jeddah. Though the present conditions of the Old City Jeddah is not unique in the region, what is unique is that the most significant changes here have occurred in the areas on the west of Al Dhahab Street, leaving most areas on the east of the street unchanged (Figures 5 \& 6). Therefore, the Old City of Jeddah provides a natural setting for a study comparing the movement patterns in the streets of its newer and older areas. 


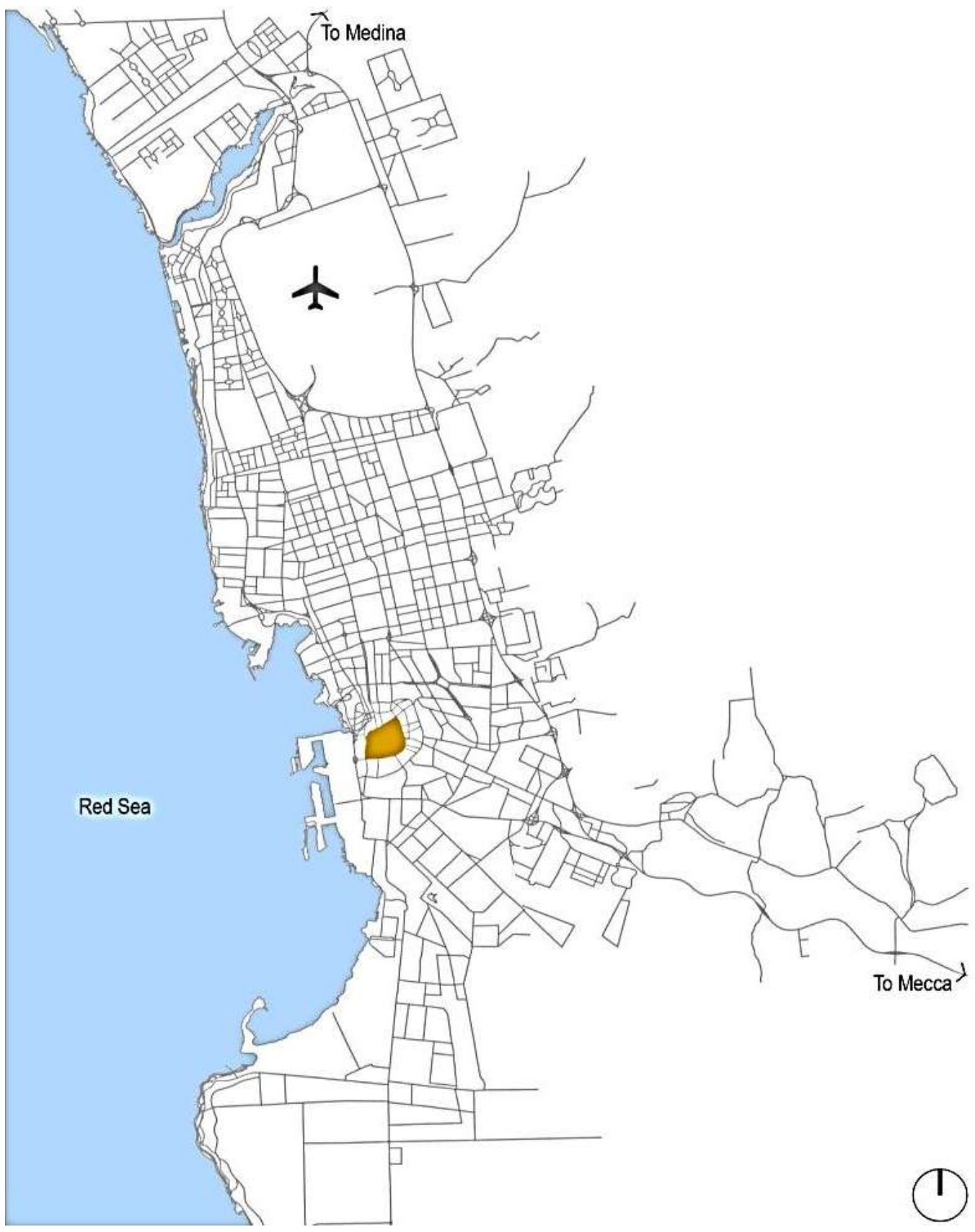

Figure 1: The City of Jeddah at present with the Old City at the center. (Drawn by Authors) 


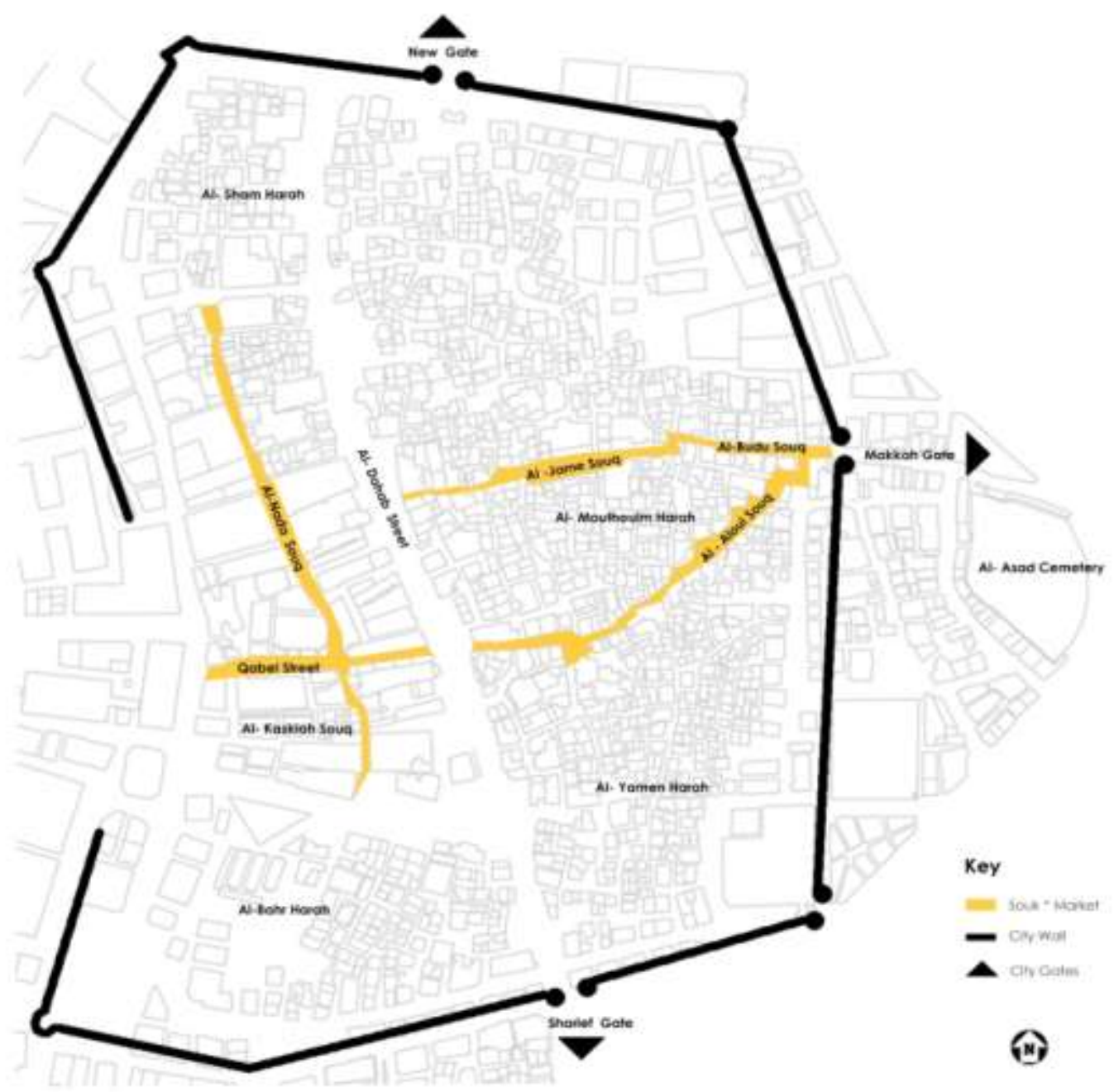

Figure 2: A map of the Old City of Jeddah with important streets, suqs, buildings and landmarks. The location of the Old City Wall is shown in lighter shade. (Drawn by Authors based on a map from the book: Angelo P (1977) Jiddah, portrait of an Arabian city. Falcon Press, Jeddah, KSA) 


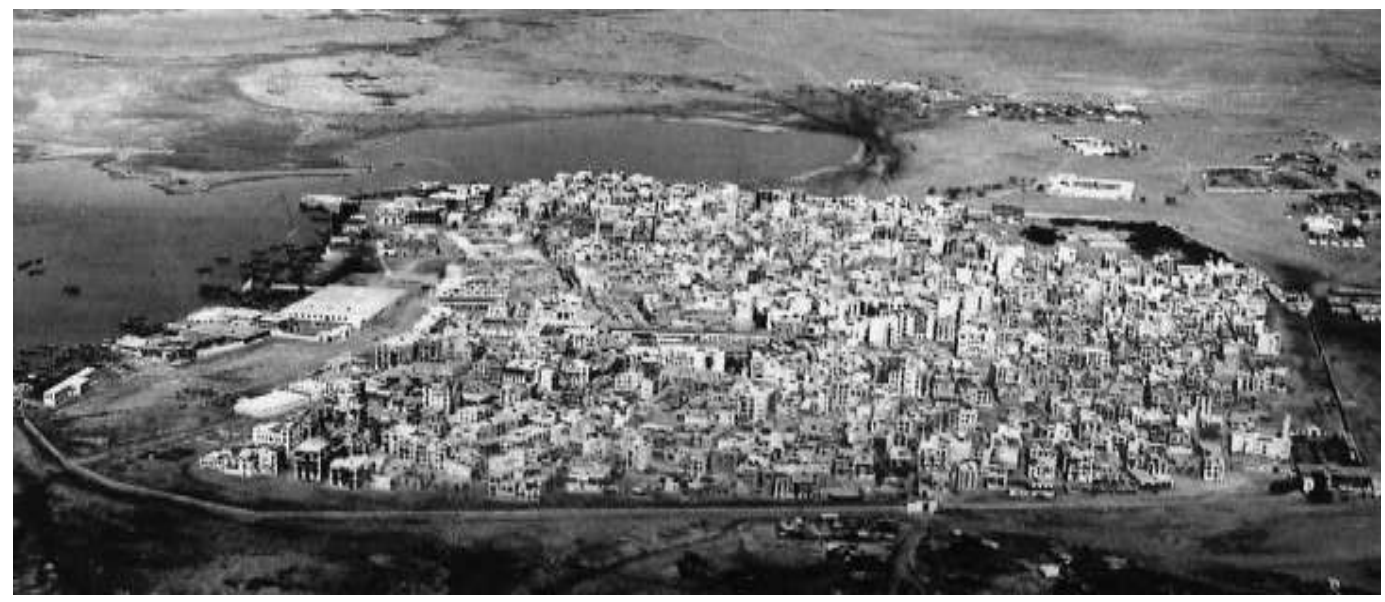

Figure 3: A 1938 aerial view of the Old City of Jeddah. (Source: Wikipedia. Retrieved Nov 05, 2014, from http://en.wikipedia.org/wiki/File:Jeddah-1938.jpeg)

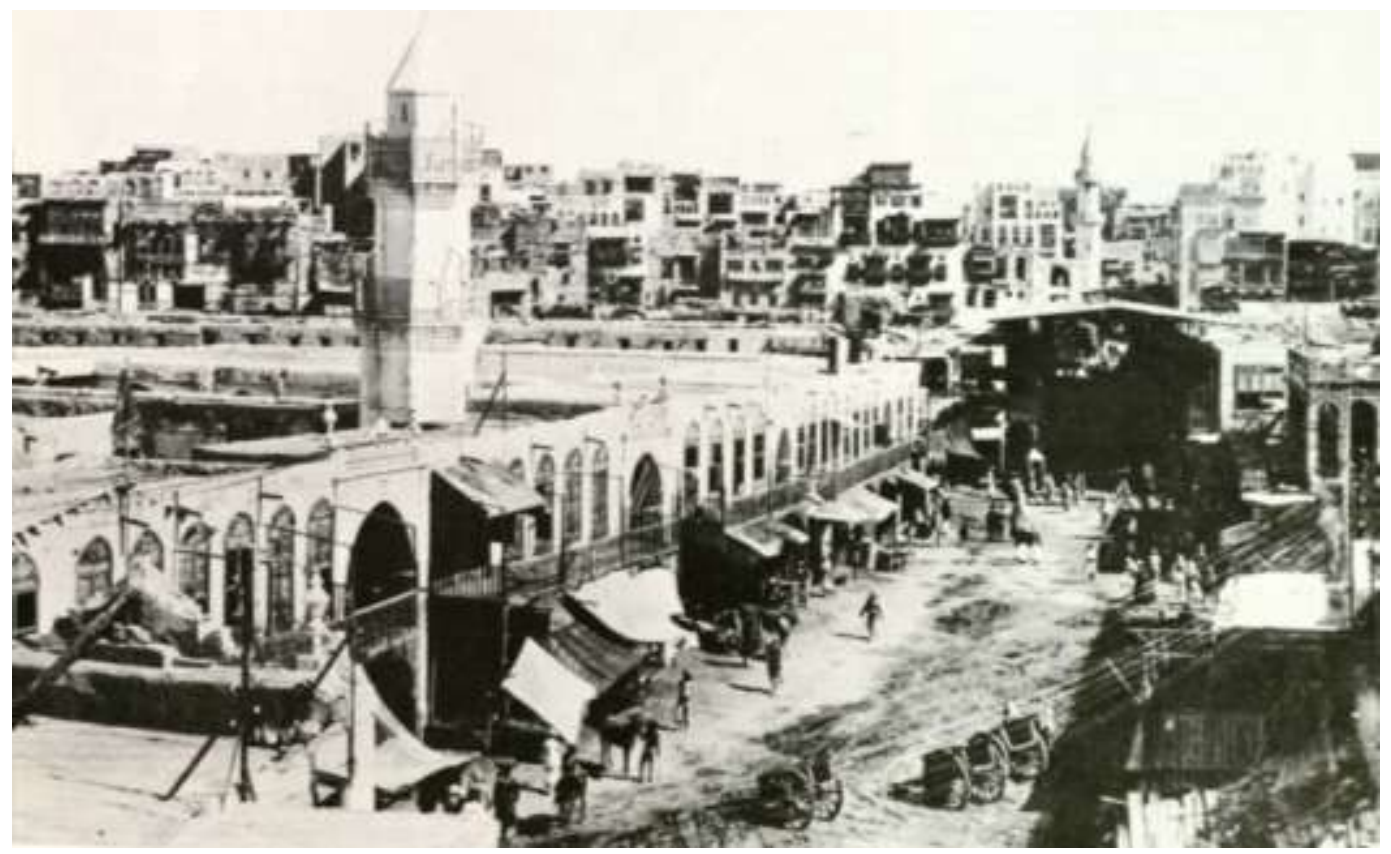

Figure 4: A 1920 street view of the Old City of Jeddah. (Used with permission from the Jeddah

City Government. Retrieved on Nov 06, 2014, from

http://www.jeddah.gov.sa/english/Gallery/index.php\#11)

As a result of many changes, the street systems of in the newer areas on the west side of $\mathrm{Al}$

Dhahab Street are more regular than they are in the older areas on the east side of the street. 
Streets are also wider and straighter in the newer western areas. The traditional hierarchy of streets and alleyways are also not found in the streets of the newer western areas. Additionally, open spaces have changed from being an integral part of the built environment to being isolated entities surrounded by fences and streets in the newer areas of the Old City.

The forms and functions of buildings have also changed significantly in the areas on the west side of Al Dhahab Street of the Old City of Jeddah. Many buildings are higher than six stories in the newer western areas, whereas buildings are generally lower than six stories in the older eastern areas. The foot prints of the buildings are also bigger and more regular in the areas on the west of Al Dhahab Street (Figure 5). With the exception of a few residential buildings, most buildings in the western areas serve retail functions. The opposite is true for the buildings in the eastern areas of the Old City, where, with the exception of a few buildings serving retail functions along the historic suqs, most buildings serve residential functions (Figure 6). 


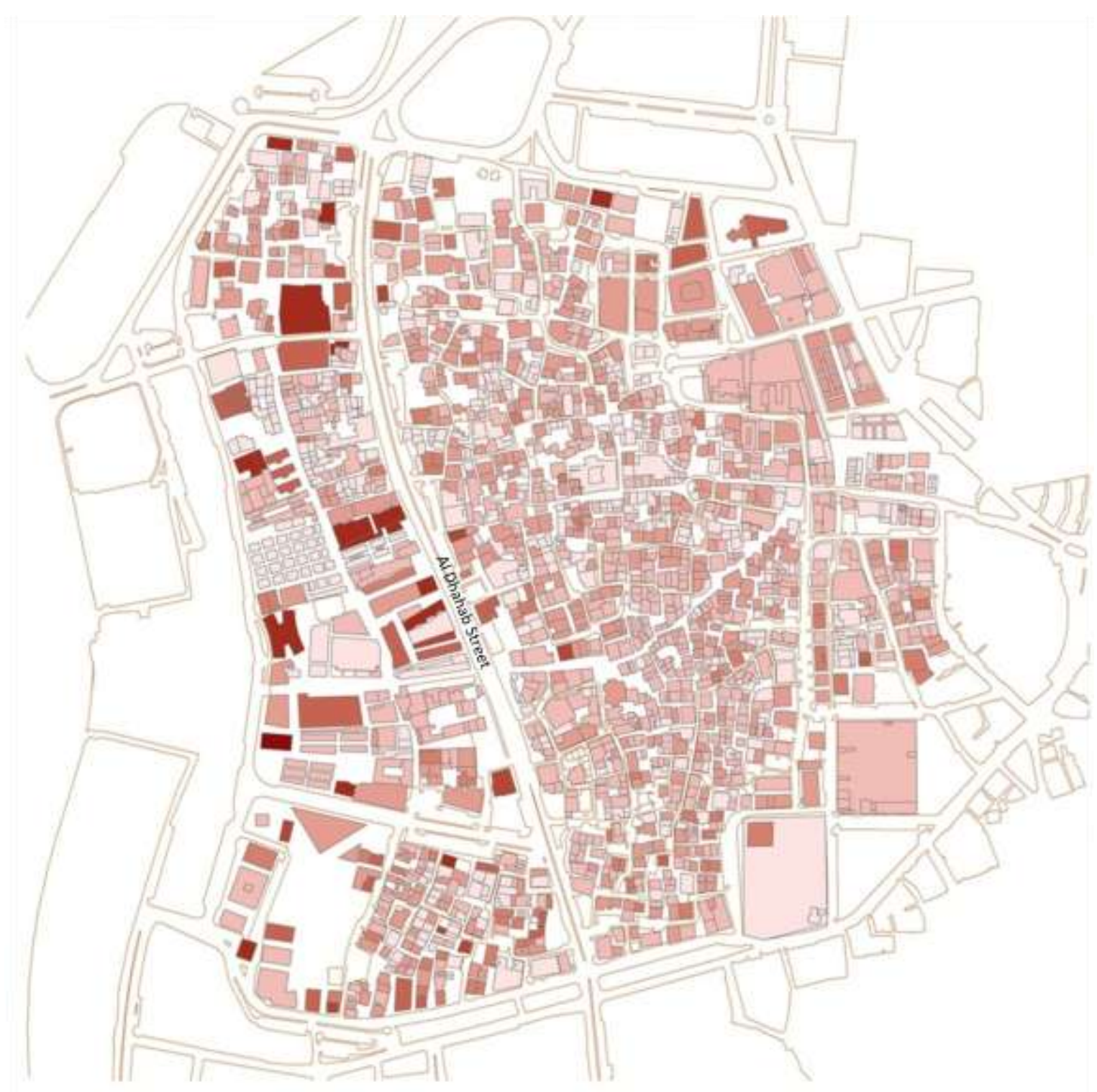

Heights of Buildings

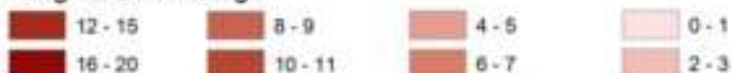

Figure 5: A map showing the heights of the building in the Old City of Jeddah. (Used with permission from the Jeddah City Government) 

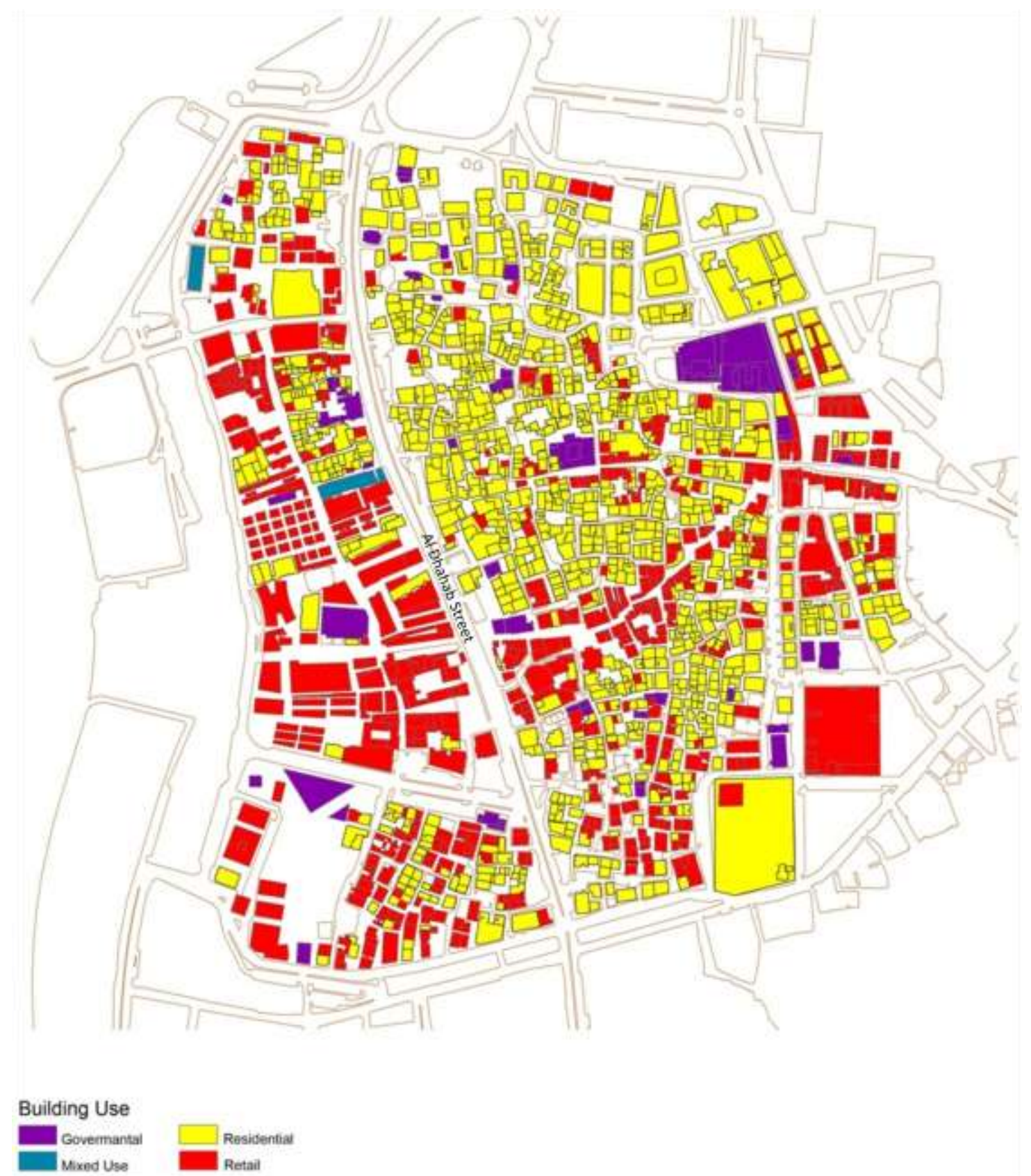

Figure 6: A map showing building use in the Old City of Jeddah. (Used with permission from the Jeddah City Government)

Therefore, the study wants to know if movements of people and cars in the streets of the newer western areas and the older eastern areas of the Old City are different due to the differences observed above in building forms and functions. This is important because very high movement 
densities can intensify the process of deterioration of the Old City. The study also wants to know the effects of the configuration of street systems on movements of people and cars in the Old City. This is important because, as noted above, many recent studies using space syntax (see below for more) have shown that the configuration of street systems have significantly strong effects on movement patterns in cities (for example, Baran, Rodríguez, \& Khattak, 2008; Hillier, 1996; Hillier \& Iida, 2005; Hillier, et al., 1993; Peponis et al., 1989; Peponis, Ross, \& Rashid, 1997).

Many scenarios can be imagined concerning the effects of spatial configuration on movements of people and cars. In one scenario, street configuration would sufficiently explain any variations in movements of both people and cars in the Old City. In another scenario, some differences would exist in the way street configuration affects people and cars in the Old City of Jeddah. In yet another scenario, some differences would exist in the way street configuration affects people and cars in the newer and older areas of the Old City. Each of these scenarios would have different implications for the future of the Old City.

Therefore, the movement patterns of people and cars for different days, functions, and street types in the newer and older areas of the Old City are compared. The configurations of street systems of the newer and older areas of the Old City of Jeddah are studied. Additionally, the effects of the street systems on the movement patterns of people and cars for different days, functions, and street types in the Old City of Jeddah are identified. The fine-grain analyses of the study should help us understand the precise nature of the effects of changes in the street systems on the movement patterns of people and cars in the Old City of Jeddah and many other similar cities in Islamic societies for better heritage planning. 


\section{METHODOLOGY}

The study was conducted in three phases. In the first phase, movements of people and cars were recorded in the field. In the second phase, the configuration of street systems of the Old City of Jeddah was studied using space syntax techniques. In the third phase, the effects of street configuration on movement were studied using correlational analysis.

\section{Field Observations}

For the purpose of the study, movement of cars and people in the streets of the Old City of Jeddah were observed and recorded along a 3-mile long route (Figure 7), with more than 45 route-segments covering both the newer and older areas of the city. Nearly half of these routesegments were in the newer areas on the west side of Al Dhahab Street, and the other half of the route-segments were in the older areas on the east side of Al Dhahab Street.

The route-segments also represented different types of streets and building functions. The streets were classified as major, secondary, and local streets. Major streets primarily provided through traffic movement from one area of the city to another. For these streets, access to adjacent areas and functions in the Old City was a secondary consideration. Secondary streets provided through traffic as well as connections to local streets providing access to adjacent areas and functions. Local streets served as a destination for the adjacent properties and functions, while providing travel needs over relatively short distances. They collected traffic from local areas and residential neighborhoods and channeled it into the secondary and primary streets. 


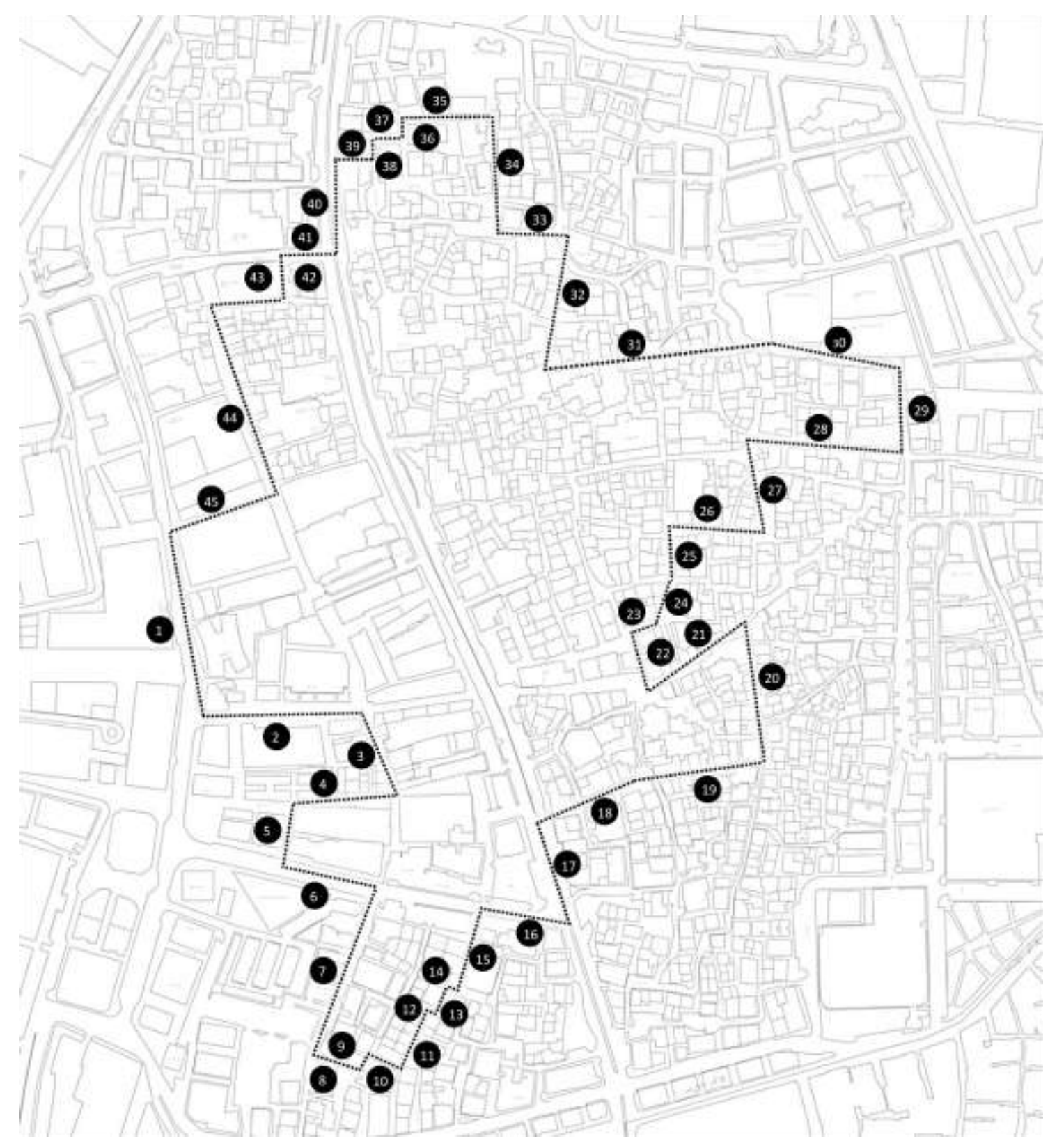

Figure 7: A map showing the observation route in the Old City. (Drawn by Authors)

Different type of functions along a route-segment included residential, retail/commercial, and mixed-use functions. The reader should note that this classification of route-segments is somewhat different from the 2010 building use map (Figure 6) developed by Jeddah Municipality. In contrast to the municipality map which shows the predominant functions of 
every building in the Old City, the functional types of route-segments only refers to the functions available at the street level of the Old City that may or may not correspond to the functions of the buildings above the street level. Therefore, in the functional classification of route-segments used here residential route-segments primarily contained residential functions at the street level; retail route-segments primarily contained retail functions at the street level; and route-segments with mixed-use functions contained some combinations of governmental, retail/commercial and residential functions at the street level.

For the study, movements of people and cars in the Old City were recorded along each of the 45 route-segments of the route by field observers over a period of 20 days starting in the morning and ending in the evening with breaks at regular intervals. The observations were completed on weekdays and weekends. Tally counters, which are devices to maintain a linear count, were used to record the numbers of people moving, standing and sitting, and to record the numbers of cars moving and parked.

Since the route-segments were different in length, observation data for each route-segment was normalized as density per 100' before statistical analyses.

\section{Configurational Analyses Using Space Syntax}

This study used the configurational analysis techniques and measures of space syntax to describe the syntactic properties of the streets of the Old City of Jeddah as an independent system, and as a part of the bigger street systems, defined by the ring roads composed of Al Amir Fahd Street, Walee Al Ahd Street, and Al Andalus Street, within which it is embedded (Figure 8). For the analysis, the Depthmap software, version 10.14.00b, was used (Turner \& Friedrich, 2010-11). 


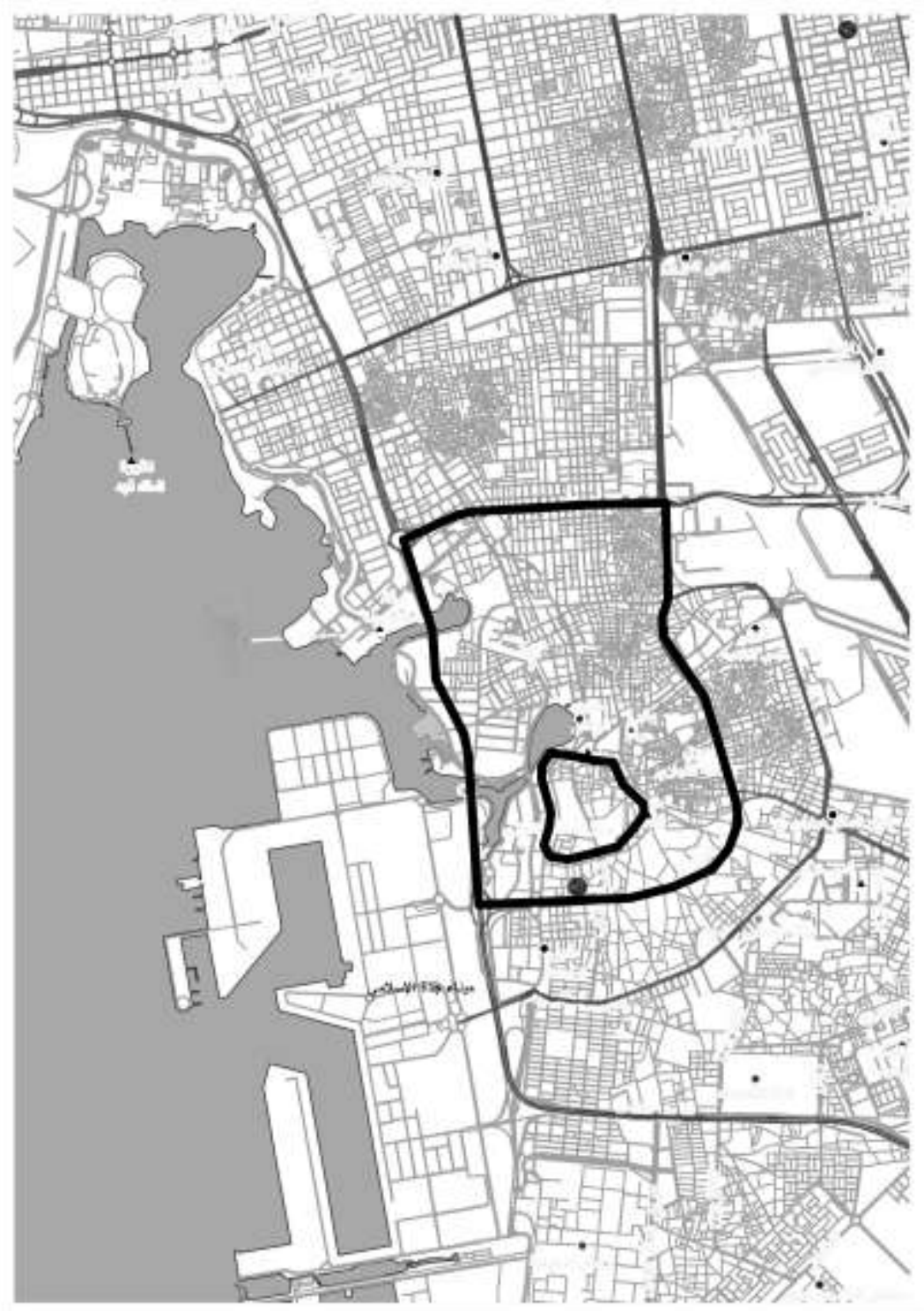

Figure 8: A map of the City of Jeddah showing the Old City (a) within the larger study area (b).

(Drawn by Authors based on a map provided by the Jeddah City Government)

The theoretical foundations for the techniques and measures of space syntax were first provided by Hillier and Hanson in The Social Logic of Space (Hillier \& Hanson, 1984), and were later elaborated by Hillier in Space is the Machine (Hillier, 1996) as well as in several other articles that followed (for example, see Hillier, $2005 \& 2008$ ). Among the many techniques of space syntax, the linear map analysis, the convex map analysis, and the visibility graph analysis are just 
a few. These techniques have been applied to the layouts of cities, districts, neighborhoods, and even individual buildings to study how centrality or accessibility (physical, visual or both) of spatial configuration affect observable phenomena as diverse as pedestrian and vehicular flows, wayfinding, crime, urban liveliness, walkability and pollution. They have been also applied to describe the organization of objects, people, and functions explaining the social and cultural logic of space.

Most space syntax studies of urban areas and cities, however, use the techniques of linear map analyses that include the axial map analysis and the more recent segment map analysis (Hillier, 2005). Both these analyses involve representing the urban layout as a linear map, which is a network of the fewest number of lines needed to cover every street and complete every circulation ring of the layout. So defined, a linear map is more commonly known as the axial map in space syntax. Earlier, the linear map of a layout was always drawn manually. Nowadays, software programs are available to automatically generate the linear map of a layout. When needed, a segment map can be generated by breaking the lines of a linear map into segments at their intersections. In the next stage of analysis, software programs use different centrality measures to describe the patterns of connections, differentiation, and centrality of the axial map and the axial lines, or of the segment maps and the segments. Finally, correlations between any observed phenomena along the axial lines or the segments and the centrality measures of the lines or their segments are studied to explain the effects of spatial patterns on these phenomena (for examples of these studies see above).

One key syntactic measure of space syntax is integration. The integration value (or the closeness value) of a line indicates how well the line is connected to all other lines in a linear map, or how close the line is to all other lines in the map. A higher integration value of a line indicates 
stronger connection of the line to the network. The integration value is also relativized to allow direct comparison between networks of different sizes (Hillier and Hanson, 1984). The integration value of the system as a whole is given by the mean of the integration values of the lines in the system. Again, the higher the integration value of a system the more connected the lines are within the system.

Using space syntax techniques it is possible to compute the integration values of lines at different radii. For example, the integration value at radius-3 of a line uses only those lines that are three steps away for the given line; the integration value at radius-5 uses only those lines that are five steps away for the given line; and so on. The integration value at radius-n of a line considers n-steps needed to cover all the lines in the system. Therefore, the integration value computed at a lower radius describes more local syntactic property than that computed at a higher radius. Note, however, that the most local of any syntactic property of a line is its connectivity value, which is the number of lines directly connected to the line.

The other major syntactic measure of space syntax is choice. While integration is about closeness, choice is about betweenness. Unlike integration, choice gives the degree to which a line lies on simplest paths from one line to another line in the network. In simple words, integration measures how easy is it to go one line to all other lines of a network, thus indicating the potential of a line for to-movement. In contrast, choice measures how likely is it for a line to be chosen on paths from one line to another in a network indicating its potential for throughmovement (Hillier, 2005). Clearly, what is implied here is that in to-movements people want to maximize their accessibility to all spaces and in through-movements people use a space to get to another space with minimum efforts. 
In space syntax, the syntactic intelligibility of an urban system is defined as the correlation between the local and global syntactic properties of the system (Hillier, 1996). An urban system is considered intelligible when the correlation is strong, because it is possible to infer the global syntactic properties more easily using the local syntactic properties in the system. Statistically, the syntactic intelligibility of an urban system is given by the coefficient of determination $R^{2}$ with a value ranging from 0 to 1 .

Based on the previous studies reported in the space syntax literature (see above for examples), it is assumed that the movement of people and cars on the streets of the Old City should show some correlations with the syntactic values of the axial lines and the segments representing the streets. More specifically, the syntactic values of the axial lines and the segments representing the Old City as an independent system should show better correlations with movement if the movement is locally oriented. In contrast, the syntactic values of the axial lines and the segments representing the Old City as a part of the larger system should show better correlations with movement if the movement is globally oriented.

\section{Statistical Analyses}

After the movement densities and the syntactic values of each route-segment were determined, IBM SSPS Statistics 20 (IBM, 2011) was used for statistical analyses. The analyses, which were done in multiple stages, included both descriptive and correlational analyses.

In the first stage of analysis, movement densities of people and cars in all the route-segments were compared with those in the route-segments of the newer and older areas of the Old City. The comparison was done based on different days of the week (weekdays and weekends), functional types, and street types. 
In the second stage of analysis, the syntactic values of the whole Old City were compared with those of the newer and older areas of the Old City. Also in the second stage of analysis, the mean syntactic values of all the route-segments were compared with those of the route-segments in the newer and older areas of the Old City. As noted above, the syntactic values were computed in two ways. First, they were computed for the Old City as an independent system (Figure 9). Then, they were computed for the Old City as a part of the bigger urban system (Figure 10). In the third stage of analysis, correlational analyses were conducted to understand the relationships between syntactic properties of and movement densities in the route segments. Again, the analysis was done based on different days of the week (weekdays and weekends), functional types and street types for all the route-segments, and for the route-segments in the newer areas and older areas of the Old City. 


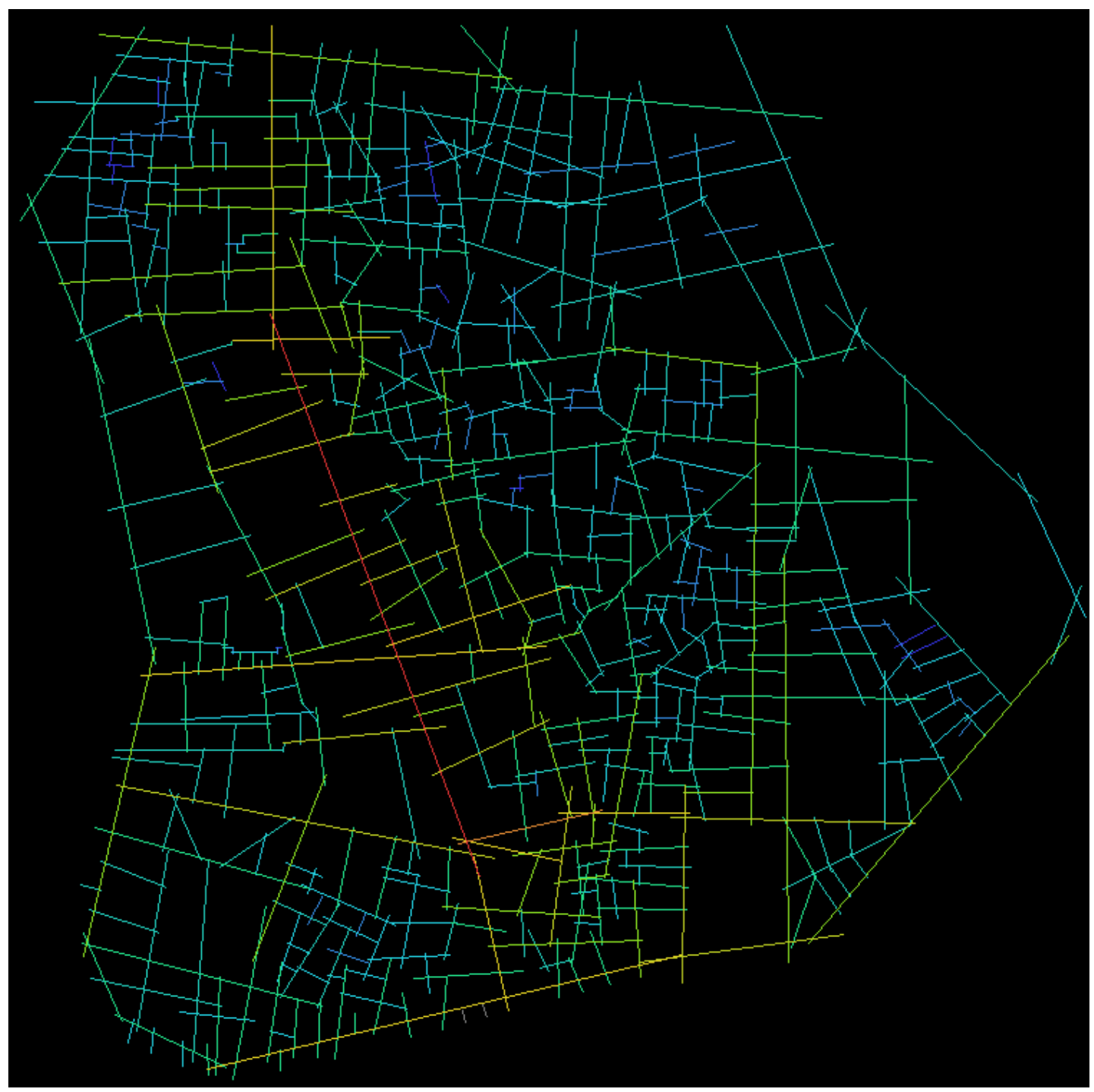

Figure 9: The axial map of the Old City colored using Integration-Rn. (Generated using Depthmap) 


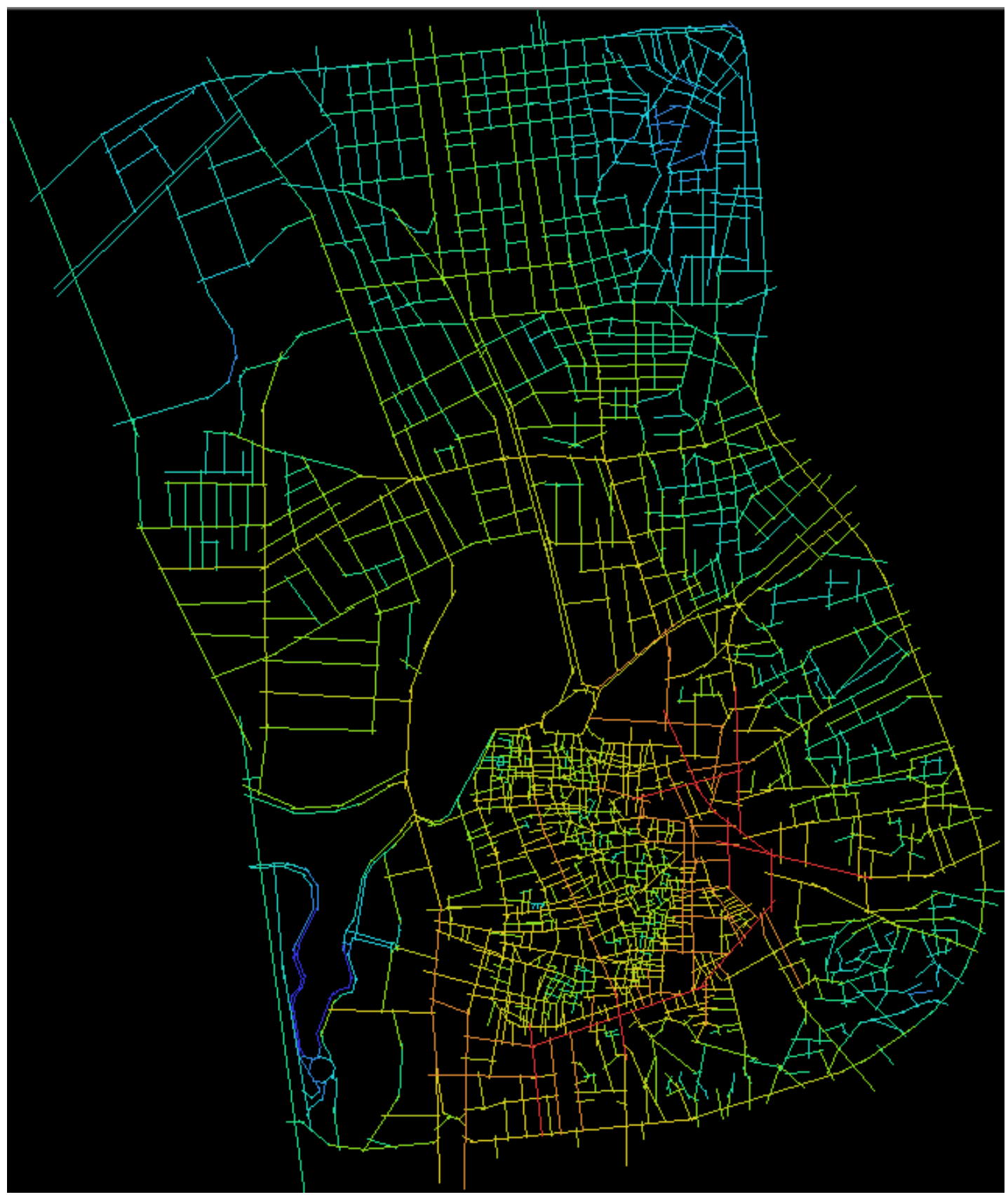

Figure 10: The axial map of the Old City embedded in the larger study area colored using Integration-Rn. (Generated using Depthmap) 


\section{RESULTS \& DISCUSSION}

\section{Results: Field Observations}

Overall movement densities (Table 1): Due to many retail and commercial functions in the bigger and taller buildings along the streets movement densities of people and cars in the newer areas were much higher than that in the older areas of the Old City. The density of moving people was 1.7 times higher; the overall pedestrian density, which included people moving, standing and sitting, was 1.82 times higher; the density of moving cars was 7.4 times higher; and the overall density of cars, which included moving and parked cars, was 8 times higher in the newer areas of the city. These findings indicate that movement densities of people and cars in the older areas of the Old City of Jeddah still may not be high enough to become a threat to the fragile but historically important urban fabric. Though optimal movement densities for urban vitality in this Old City are yet to be determined, according to our discussion in the introductory sections of this paper a strategy that will help maintain the low movement densities presently observed in the old areas may be important for limiting any further deterioration of its historic urban fabric.

Movement densities on weekdays and weekends (Table 2): Though movement densities were generally much higher in the newer areas, the movement densities of both people and cars on weekdays were not much different from that on weekends in the newer and in the older areas of the Old City. These densities remain closer to the overall mean densities in both the newer and older areas. The findings indicate that the urban life in the Old City of Jeddah has remained vibrant on both weekdays and weekends. This has been not been the case in urban 
redevelopment projects in many cities, where due to homogenous building functions urban areas would become dead at least for a few days of the week.

\begin{tabular}{|c|c|c|c|c|}
\hline Location & $\begin{array}{l}\text { Density of moving } \\
\text { people }\end{array}$ & $\begin{array}{l}\text { Overall pedestrian } \\
\text { density }\end{array}$ & $\begin{array}{c}\text { Density of moving } \\
\text { cars }\end{array}$ & Overall car density \\
\hline Route-segments in Newer Areas & 98.06 & 209.34 & 30.10 & 58.90 \\
\hline Route-segments in Older Areas & 56.89 & 114.87 & 4.07 & 7.35 \\
\hline
\end{tabular}

Table 1: Overall movement densities along the route-segments.

\begin{tabular}{|c|c|c|c|c|c|}
\hline Location & & $\begin{array}{c}\text { Density of } \\
\text { movingpeople }\end{array}$ & $\begin{array}{c}\text { Overall pedestrian } \\
\text { density }\end{array}$ & $\begin{array}{l}\text { Density of } \\
\text { moving cars }\end{array}$ & $\begin{array}{l}\text { Overall car } \\
\text { density }\end{array}$ \\
\hline \multirow{3}{*}{ Route-segments in Newer Areas } & weekdays & 97.66 & 217.89 & 27.16 & 56.29 \\
\hline & weekends & 98.47 & 200.79 & 33.05 & 61.51 \\
\hline & Mean & 98.06 & 209.34 & 30.10 & 58.90 \\
\hline \multirow[t]{2}{*}{ Route-segments in Older Areas } & weekends & 53.32 & 114.77 & 3.99 & 7.31 \\
\hline & Mean & 56.89 & 114.87 & 4.07 & 7.35 \\
\hline
\end{tabular}

Table 2: Movement densities on weekdays and weekends in the newer areas and older areas of the Old City.

Movement densities and street types (Table 3): The density of moving people and the overall pedestrian density were the highest in the local streets, followed by that in the secondary streets, and then by that in the major streets of the newer areas of the Old City. The same is not true for the density of moving cars and the overall car density in the newer areas. Here, the density of moving cars and the overall car density were the highest in the major streets, followed by that in the secondary streets, and then by that in the local streets. The findings would indicate that 
people in the newer areas of the Old City of Jeddah walked less on the streets with more cars, but people and cars have not become totally separated in the streets of the Old City. This is in contrast to urban redevelopment projects in many cities, where strongly designed vehicular and pedestrian streets kept pedestrian separate from cars. As a result, they managed to destroy healthy relationships between pedestrian and cars, which would be essential for urban liveliness argued Jane Jacobs (1961) and Christopher Alexander (1966).

\begin{tabular}{|c|c|c|c|c|c|}
\hline Location & & $\begin{array}{l}\text { Density of moving } \\
\text { people }\end{array}$ & $\begin{array}{c}\text { Overall pedestrain } \\
\text { density }\end{array}$ & $\begin{array}{l}\text { Density of } \\
\text { moving cars }\end{array}$ & $\begin{array}{c}\text { Overall car } \\
\text { density }\end{array}$ \\
\hline \multirow{3}{*}{ Newer Areas } & Major street & 57.43 & 128.21 & 33.73 & 73.40 \\
\hline & Secondary street & 81.29 & 181.03 & 32.83 & 65.94 \\
\hline & Local street & 130.90 & 271.60 & 26.38 & 46.51 \\
\hline \multirow{4}{*}{ Older Areas } & Major street & 87.17 & 150.71 & 27.24 & 39.93 \\
\hline & Secondary street & 23.80 & 46.78 & 4.42 & 11.74 \\
\hline & Local street & 61.68 & 128.24 & 0.89 & 1.84 \\
\hline & Mean & 56.89 & 114.87 & 4.07 & 7,35 \\
\hline
\end{tabular}

Table 3: Movement densities on different streets in the newer areas and older areas of the Old City.

According to the findings, the density of moving people and the overall pedestrian density were the highest in the major streets, followed by that in the local streets, and then by that in the secondary streets of the older areas. Again, the same is not true for the density of moving cars and the overall car density in the older areas of the Old City. Here, the density of moving cars and the overall car density were the highest in the major streets, followed by that in the secondary streets, and then by that in the local streets of the older areas. In fact, the local streets of the older areas had very few cars. These findings indicate that people and cars used the major streets most in the older areas of the city, though the densities of people were much higher than 
that of cars. The findings also indicate that people used the local streets far more densely than cars in the older areas of the Old City. This is important because higher densities of cars could destroy the Old City more easily than higher densities of people.

Movement densities and building functions (Table 4): Movement densities of both people and cars were the highest in the mixed-use areas; followed by that in the retail areas; and then by that in the residential areas of the newer areas of the Old City of Jeddah. In contrast, movement densities of both people and cars were the highest in the retail areas; followed by that in the mixed-use areas; and then by that in the residential areas of the older areas of the Old City of Jeddah. The streets with mixed-use functions showed very high densities of people and cars in the newer areas of the Old City, because these areas have several large and tall buildings that serve retail functions at the lower levels and office and residential functions at the upper levels. In contrast, the older areas do not have large and tall mixed-used buildings, but they have the famous suqs with very high densities of people and cars. Finally, residential streets in both the newer and older areas of the Old City had moderate densities of people and low to zero densities of cars. This absence of cars in the residential streets of the older areas is particularly encouraging from a heritage planning perspective, because most of the traditional urban fabric of the Old City is made up of residential streets. One could only speed up the deterioration of this fabric with more cars moving through these streets.

Configurational analyses presented in the next section is aimed at showing if the variations in movement densities of people and cars in the streets of the Old City of Jeddah observed above can be explained by its spatial configuration, or if social and cultural norms of the Old City are still a factor affecting movement densities in its streets. 


\begin{tabular}{|c|c|c|c|c|c|}
\hline Location & & $\begin{array}{l}\text { Density of moving } \\
\text { people }\end{array}$ & $\begin{array}{l}\text { Overall pedestrain } \\
\text { density }\end{array}$ & $\begin{array}{c}\text { Density of moving } \\
\text { cars }\end{array}$ & $\begin{array}{l}\text { Overall car } \\
\text { density }\end{array}$ \\
\hline \multirow{3}{*}{ Newer Areas } & Mixeduse & 115.62 & 250.45 & 39.88 & 79.80 \\
\hline & Residential & 71.58 & 132.07 & 0.00 & 0.00 \\
\hline & Retail & 82.29 & 175.46 & 24.39 & 45.60 \\
\hline \multirow{4}{*}{ Older Areas } & Mixeduse & 60.21 & 114.53 & 0.90 & 1.80 \\
\hline & Residential & 48.43 & 106.25 & 2.08 & 5.30 \\
\hline & Retail & 120.15 & 212.69 & 54.48 & 79.85 \\
\hline & Mean & 56.89 & 114.87 & 4.07 & 7.35 \\
\hline
\end{tabular}

Table 4: Movement densities on streets with different functions in the newer areas and older areas of the Old City.

\section{Results: Configurational Analyses}

The results of the two levels of configurational analyses - the Old City as an independent system and the Old City as a part of the larger urban system - are shown in Table 5. The table shows the integration-Rn values of the newer areas, older areas, and the whole Old City of Jeddah, and that of the route-segments in the newer areas, older areas, and in the whole Old City of Jeddah. Within any one of the two levels of configurational analysis, the integration values of the two areas of the Old City and that of the route-segments in the two areas are comparable. However, between the two levels of configurational analysis the integration values of the two areas and that of the route-segments in the two areas of the Old City are different. The differences are indicated by the higher integration values of the two areas and that of the route-segments in the two areas within the Old City as an independent system. In other words, the Old City is much better integrated as an independent system than it is as a subsystem within a larger system. 


\begin{tabular}{|l|c|c|}
\hline & $\begin{array}{c}\text { Integ-Rn (Historic Core as an } \\
\text { Independent System) }\end{array}$ & $\begin{array}{c}\text { Integ-Rn (Historic Core } \\
\text { Embedded in the Larger } \\
\text { System) }\end{array}$ \\
\hline Newer Areas & 1.36 & 0.95 \\
\hline Older Areas & 1.28 & 0.97 \\
\hline Whole Historic Core & 1.31 & 0.96 \\
\hline Route-Segments in Newer Areas & 1.43 & 0.93 \\
\hline Route-Segments in Older Areas & 1.40 & 0.94 \\
\hline The Whole Route & 1.42 & 0.93 \\
\hline
\end{tabular}

Table 5: Mean Integration -Rn values of the newer and older areas and of the route-segments in the newer and older areas in the Old City at two different levels of configurational analysis.

The syntactic independence of the Old City as a system from the larger system is also emphasized by the locations of the integration cores - defined by the most integrated set of axial lines shown in Red - at the two levels of configurational analysis (Figures 9 \& 10). When the Old City is considered as an independent system, the core is located at the center of the core along Al Dhahab Street (Figure 9). However, when the core is considered as a subsystem within the larger system, the integration core moves out of the Old City to the periphery along the streets where the Old City wall was once located (Figure 10); thus, providing an interface between the Old City and the new city beyond and highlighting the differences between the old and the new cities.

The syntactic independence of the Old City from the larger system is further emphasized by the intelligibility of the Old City as a system. For the study, the intelligibility values of the Old City and its newer and older parts were determined using bivariate correlations among connectivity, 
integration R3, integration R5, and integration Rn (Table 6). In all cases, the correlations are strong and statistically significant at the 0.01 level. With the exception of a few isolated cases (shown in bold in Table 6), the intelligibility values of the Old City and its newer and older parts are higher if the Old City is considered as an independent system than the intelligibility values if the Old City is considered as a part of the larger system.

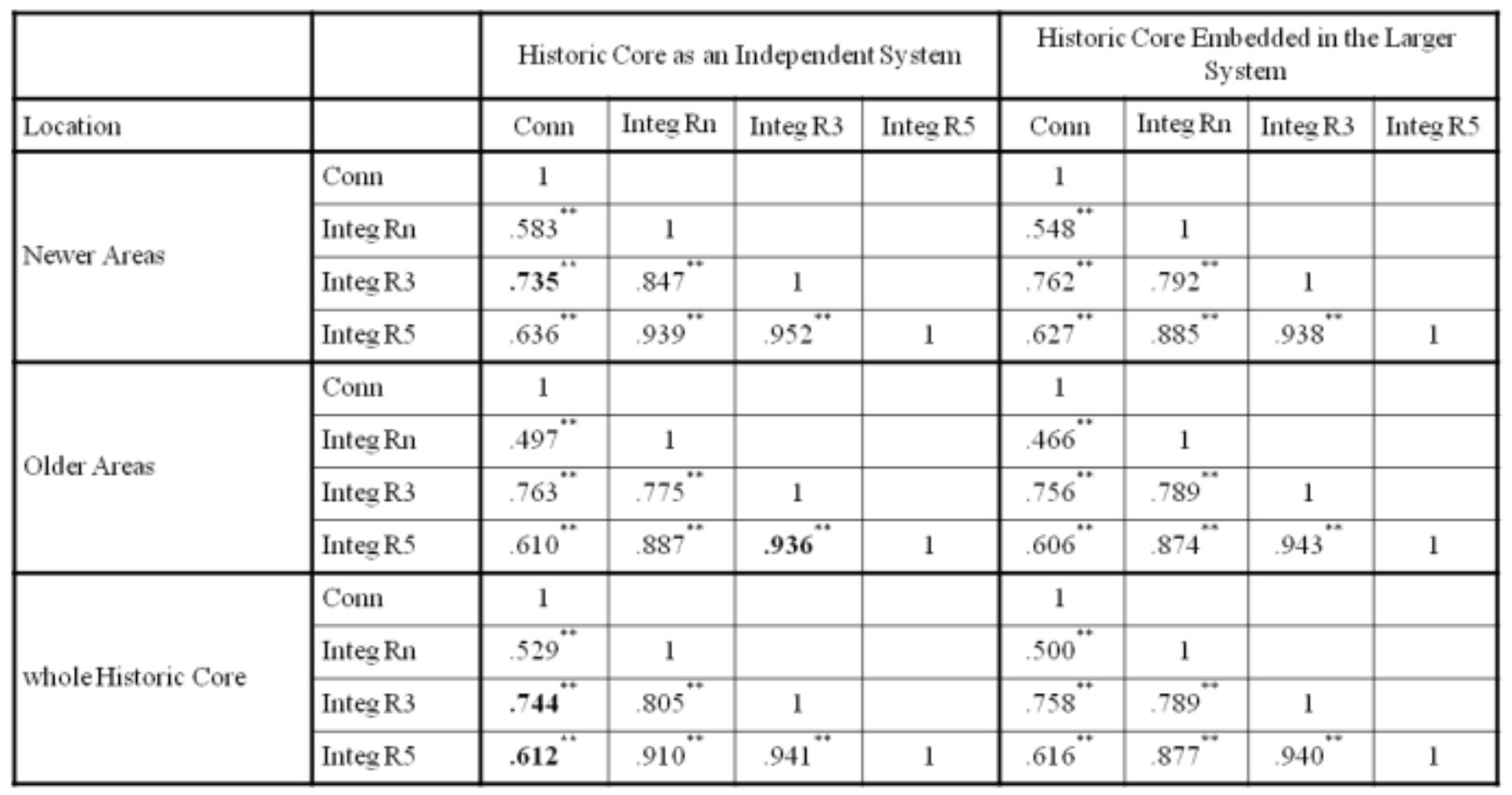

**. Conrelation is significant at the 0.01 level (2-tailed).

Table 6: Correlations among different syntactic values indicating intelligibility of the Old City at two different levels of configurational analysis.

One wonders if the syntactic integrity of the Old City as an independent system and the syntactic independence of the Old City from the larger urban system, as identified in the above syntactic analyses, could have played a positive role in restricting a more intense onslaught of redevelopment projects within of the Old City of Jeddah, and if such a syntactic approach could 
be used as a strategy for the preservation of the Old City in other cities. Therefore, a need for further studies involving other similar cities is indicated.

\section{Results: Correlational Analyses among Movement Densities and Syntactic variables}

Correlational analyses involving various syntactic measures and movement densities were conducted for different days, functions and street types. Tables 7-9 present only the significant correlations of the analyses.

Correlations for different days (Table 7): The correlations between different syntactic variables and movement densities for the weekdays, weekends, and for the whole week indicate that the densities of cars had stronger relationships with syntactic variables regardless of which day of the week one considers.

In most instances, the densities of moving cars showed positive and significant correlations with the local and global syntactic variables for the weekdays, weekends, and for the whole week. These relationships were stronger for local than global syntactic variables. This is further supported by the fact that topological choice (which is a global syntactic value measuring the potential of a path for through-movement) showed no significant correlation with the densities of moving cars.

The overall densities of cars (which included both moving and parked cars) also showed positive and significant correlations with the local and global syntactic variables for the weekdays, weekends, and for the whole week; and, again, these relationships were stronger for the local than global syntactic variables. However, in contrast to the densities of moving cars, the overall densities of cars on the streets of the Old City showed weak and somewhat significant 
correlations with topological choice over the whole week indicating that the presence of cars on these streets may be somewhat related to how they are chosen as paths on way to other places.

\begin{tabular}{|c|c|c|c|c|c|c|c|c|}
\hline & & $\begin{array}{l}\text { Integ Rn } \\
-\mathrm{HC}\end{array}$ & $\begin{array}{c}\text { Integ R3 } \\
-\mathrm{HC}\end{array}$ & $\begin{array}{l}\text { Integ Rn } \\
\text { - HCLS }\end{array}$ & $\begin{array}{l}\text { Integ R3 } \\
\text { - HCLS }\end{array}$ & Conn & $\begin{array}{l}\text { Topological } \\
\text { Choice- HC }\end{array}$ & $\begin{array}{c}\text { Topological } \\
\text { Choice- } \\
\text { HCLS }\end{array}$ \\
\hline \multirow{2}{*}{ All Days $(\mathrm{n}=90)$} & Overall pedestrian density & & & & $.258^{*}$ & $.287^{*}$ & & \\
\hline & Density of moving cars & $259^{*}$ & $388^{* *}$ & $.218^{*}$ & $415^{*}$ & $530^{* *}$ & & \\
\hline \multirow[t]{4}{*}{ Weekdays $(n=45)$} & Density of movingpeople & & & & $.304^{*}$ & $314^{*}$ & & \\
\hline & Overall pedestrian density & & & & & $314^{*}$ & & \\
\hline & Density of moving cars & $331^{*}$ & $451^{* *}$ & & $477^{*}$ & $599^{* *}$ & & \\
\hline & Overall car density & $.395^{* *}$ & $456^{* *}$ & $321^{*}$ & $476^{* *}$ & $589^{* *}$ & & \\
\hline \multirow{2}{*}{ Weckends $(n=45)$} & Density of moving cars & & $341^{\circ}$ & & $.369^{*}$ & $479^{* *}$ & & \\
\hline & Overall car density & $315^{*}$ & $.402^{* *}$ & & $429^{* *}$ & $.537^{* *}$ & & \\
\hline
\end{tabular}

**. Correlation is significant at the 0.01 level (2-tailed).

*. Correlation is significant at the 0.05 level (2-tailed).

Integ - Integration. Com - Connectivity. HC - Historic Core. HCLS - Historic Core Embedded in Larger System

Table 7: Correlations among movement densities and syntactic values for different days of the week.

The densities of moving people and the overall pedestrian densities showed weak but significant correlations with integration-R3 (computed with the Old City embedded in the larger system) and connectivity for the weekdays and the whole week, but not for weekends. These findings indicate that while space had some associations with the distribution of the movement densities of people on weekdays and throughout the week, there were no such associations during the weekends referring to the fact that life in the city on weekdays may be different from that on the weekends. 
Overall, the densities of cars showed more correlations with the syntactic variables than the densities of people showed for different days of the week in the Old City of Jeddah. This makes sense in light of the previous studies, which showed that the movement of cars was generally affected less by local functional variations than the movement of people (Hillier, 1996). If this were to be true also for the Old City of Jeddah, then the densities of cars should show stronger correlations with the syntactic variables for its major streets than its minor streets, because the movement of cars occurs more on major streets and less on local streets. Correlational analyses verifying the claim are presented next.

Correlations for street types (Table 8): The correlations among the local and global syntactic variables and the densities of cars were significantly strong for the major streets of the Old City of Jeddah. These correlations were found for both integration and choice indicating that the densities of cars on the major streets of the city resulted from both through-and to-movements.

The correlations among the local and global syntactic variables and the densities of people were also significantly strong for the major streets of the Old City of Jeddah. While the correlation coefficient varied between 0.509 and 0.853 for pedestrian densities, it varied between 0.745 and 0.921 for car densities indicating that the densities of cars generally were more strongly associated with the syntactic variables than that of people in the major streets of the Old City.

For the secondary streets, the correlations among the local and global syntactic variables and the densities of people were significantly strong in several cases and that among the syntactic variables and the densities of car were significant in fewer cases only. These findings indicate that the densities of people were affected more by spatial configuration than that of cars in the secondary streets of the Old City. 
For the local streets of the Old City of Jeddah, the relationships between the local and global syntactic variables and the densities of people were also significant in several cases. Interestingly enough, while the movement densities of people showed significant positive correlations with local integration and connectivity, they showed significant negative correlations with choice. These findings indicate that the movement density of people on a local street increases as the potential of the street to carry to-movement increases. Conversely, they also indicate that the movement density of people on a local street decreases as the potential of the street to carry through-movement increases.

\begin{tabular}{|c|c|c|c|c|c|c|c|c|}
\hline Type of streets & & $\begin{array}{l}\text { Integ } \\
\mathrm{Rn}- \\
\mathrm{HC}\end{array}$ & $\begin{array}{l}\text { Integ } \\
\mathrm{R} 3- \\
\mathrm{HC}\end{array}$ & $\begin{array}{l}\text { Integ } \\
\text { Rn - } \\
\text { HCLS }\end{array}$ & $\begin{array}{c}\text { Integ } \\
\text { R3 - } \\
\text { HCLS }\end{array}$ & Conn & $\begin{array}{c}\text { Topological } \\
\text { Choice - } \\
\text { HC }\end{array}$ & $\begin{array}{c}\text { Topological } \\
\text { Choice - } \\
\text { HCLS }\end{array}$ \\
\hline \multirow[t]{4}{*}{ Major street $(n=16)$} & Density of moving people & $.509^{*}$ & $.672^{* *}$ & $.705^{* *}$ & $.789^{* *}$ & $.853^{*}$ & & \\
\hline & Overall pedestrian density & $.527^{*}$ & $.595^{\circ}$ & $.626^{* *}$ & $.739^{* *}$ & $.753^{*}$ & & $.542^{*}$ \\
\hline & Density of moving cars & $.776^{* *}$ & $.854^{* *}$ & $884^{*-}$ & $.921^{* *}$ & $.854^{*-}$ & $.556^{*}$ & $.837^{* *}$ \\
\hline & Overall car density & $.880^{*-}$ & $.745^{* *}$ & $.806^{* *}$ & $.836^{* *}$ & $.796^{* *}$ & $.541^{*}$ & $.811^{* *}$ \\
\hline \multirow[t]{4}{*}{ Secondary street $(n=22)$} & Density of moving people & $.556^{* *}$ & $.599^{* *}$ & & $.662^{* *}$ & $.724^{* *}$ & & \\
\hline & Overall pedestrian density & $.566^{* *}$ & $.594^{* *}$ & & $.659^{* *}$ & $.720^{*-}$ & & \\
\hline & Density of moving cars & & & & $487^{*}$ & $.543^{* *}$ & & \\
\hline & Overall car density & & & & $446^{*}$ & $498^{*}$ & & \\
\hline \multirow[t]{4}{*}{ Local street $(\mathrm{n}=52)$} & Density of moving people & & & & $326^{*}$ & $377^{* *}$ & $-334^{*}$ & \\
\hline & Overall pedestrian density & & & & $.286^{*}$ & $346^{*}$ & $-354^{* *}$ & \\
\hline & Density of moving cars & & & & & $.292^{*}$ & & \\
\hline & Overall car density & & & & & $.377^{* *}$ & & \\
\hline
\end{tabular}

**. Correlation is significant at the 0.01 level (2-tailed).

*. Correlation is significant at the 0.05 level (2-tailed).

Integ - Integration. Conn - Connectivity. HC - Historic Core. HCLS - Historic Core Embedded in Larger System

Table 8: Correlations among movement densities and syntactic values for different types of streets. 
In general, local streets showed far fewer correlations with movement densities than primary and secondary streets. This is important because it indicates that movement densities in local streets may still be dependent on socio-cultural and religious norms of the Old City.

Overall, the interaction effects of street types on the relationships between the densities of people and the syntactic variables were more systematic than the interaction effects of street types on the relationships between the densities of cars and the syntactic variables in the Old City of Jeddah. Therefore, if one observes a disassociation between movement and space in different types of streets in the Old City, it may not be due to a lack of the relationship between space and people in its streets. Rather, any sense of disassociation between space and movement may occur in the Old City due to a lack of relationship between space and cars in its streets.

Correlations for different functions (Table 9): There were no correlations among the local and global syntactic variables and the densities of people in the mixed-use streets of the Old City of Jeddah. In contrast, there were many significant positive correlations between the local and global syntactic variables and the densities of cars in the mixed-use streets of the Old City.

For the residential streets, while the densities of people showed no correlations with the local and global syntactic variables measuring to-movement potential, they showed several negative correlations with the syntactic variables measuring through-movement potential. These correlations indicate, one more time, that as the potential of a residential street to carry throughmovements increases the movement density of people on the street decreases.

Also for the residential streets, while only one syntactic variable measuring to-movement potential showed somewhat significant correlation with the densities of cars, the syntactic variables measuring through-movement potential showed several significant positive correlations 
with the densities of cars. These correlations indicate that as the potential of the street to carry through-movements increases the movement density of car increases even on a residential street of the Old City.

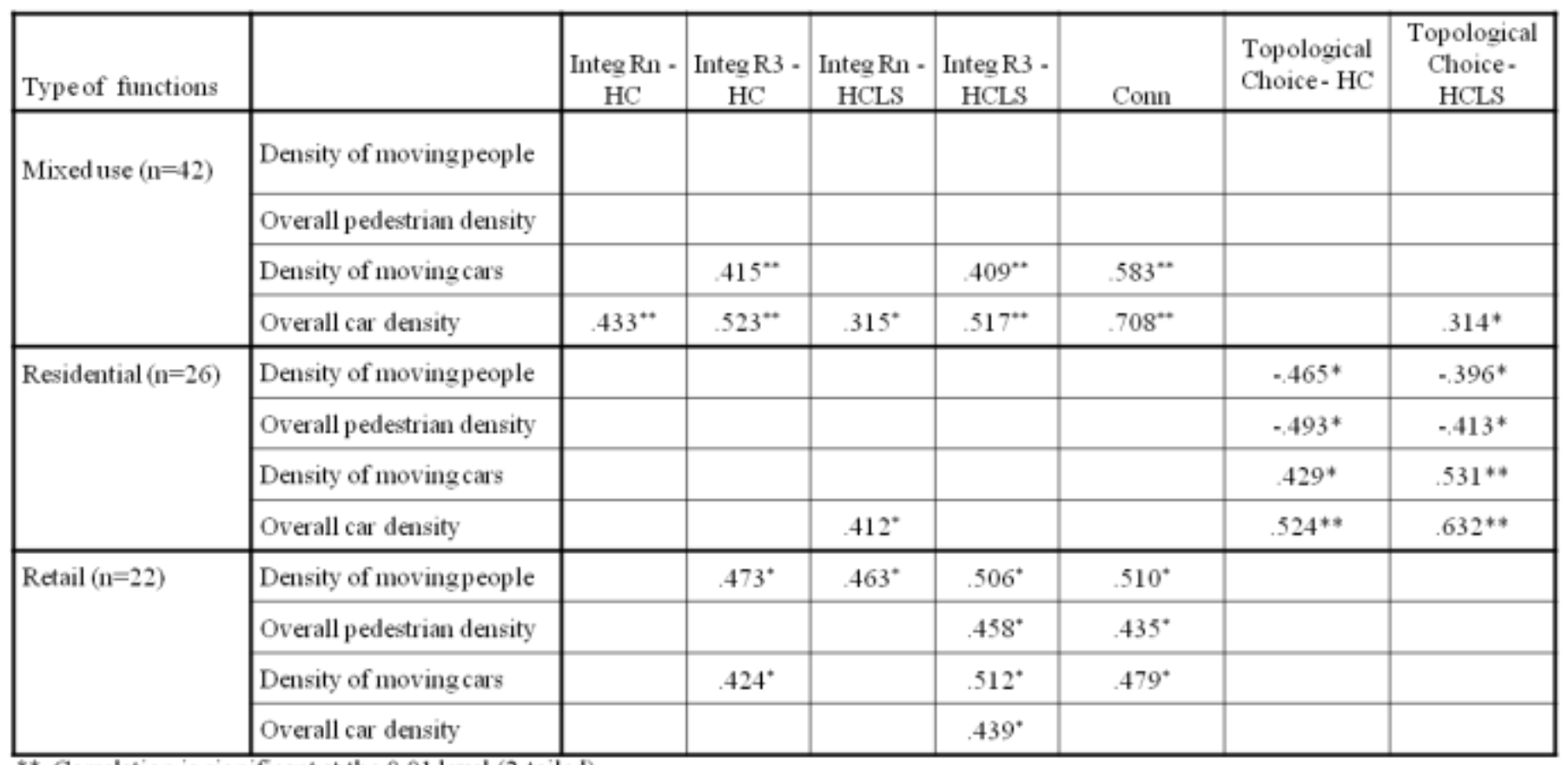

**. Correlation is significant at the 0.01 level (2-tailed).

*. Correlation is significant at the 0.05 level (2-tailed).

Integ - Integration. Conn - Connectivity. HC - Historic Core HCLS - Historic Core Embedded in Larger System

Table 9: Correlations among movement densities and syntactic values for different functions.

Finally, the local and global syntactic variables measuring to-movement potential showed several significant correlations with the densities of people and cars in the retail streets of the Old City. With the exception of one case, these correlations occur with the more local syntactic variablesintegration-R3 (computed with the Old City as an independent system and as a system embedded in the larger system) and connectivity, and indicate that the densities of movement in the retail streets of the Old City was associated more with the configuration of the local area streets than with the configuration of the larger street systems. 
Overall, the findings of the study indicate that in the Old City of Jeddah retail and mixed-use functions are different from residential functions in terms of their interaction effects on the relationships between space and movement. This may be because the former functions depend more on the flow of people, cars and goods, and the latter functions depend more on sociocultural and religious norms including privacy.

\section{CONCLUSIONS}

Recent technological, social, cultural and economic changes and their physical consequences have created a situation in most Islamic societies where the traditional historic cities are fast disappearing and/or losing relevance. There is a clear need for heritage planners to plan for what is left and to integrate the traditional historic cities into the bigger cities surrounding them. However, heritage planning of living historic cities, like the ones in Islamic societies, must be considered carefully. Maintaining a sense of continuity in function, space and community in response to the changing circumstances is essential to prevent these cities from becoming historic theme parks or slums.

It was observed in the paper that understanding the effects of space on movement patterns can be important for the heritage planning of living historic cities because, through its effects on movement patterns, space can affect land-use patterns, building densities, the mixing of uses in urban areas and the part-whole structure of the city, which are essential ingredients of lively cities. Therefore, this study looked at movement patterns of people and cars in the streets of the Old City of Jeddah in relation to its spatial configuration for learning lessons on heritage planning in historic Islamic cities. The Old City of Jeddah was selected as a case study, not only 
because it faces many problems common to other historic cities in Islamic societies but also because a large part of this city still preserves a 'genuine camaraderie' that once characterized many traditional cities in these societies.

The study reported several findings that could potentially be relevant to the heritage planning of this and other historic cities in Islamic societies. One such finding was that the street life in the Old City of Jeddah was vibrant both on weekdays and weekends during the study period. This is important for heritage planners because to keep any historic city vibrant on every day of a week can be a challenging problem. To ensure urban liveliness throughout the week, the spatial configuration of a historic city must generate sufficient movement densities to encourage multiple functions to occur simultaneously on each day of the week at an economically viable level.

In today's world, the economic viability of any historic city must depend on local and global factors. In relation to the built environment, this may require that spatial configuration be appropriately structured, locally and globally, allowing both people and cars to be present on the streets of the city. On this issue, the study reported that people in the newer areas of the Old City walked less on the streets with more cars, but they did not completely abandon these streets. This is unlike many modern areas of this and other cities where primary streets are taken over by cars with no room left for pedestrians. Therefore, the lesson that heritage planners should take from the Old City of Jeddah is that people and cars must not be allowed to become separated even on the streets that are used primarily by cars in any historic city, because it is hard to recreate traditional camaraderie without people. 
On the same issue, the study also reported that movement densities in the older areas of the city were low when compared with those in the newer areas of the Old City. In light of the arguments presented in the introductory section of the paper against high movement densities in historic cities, low movement densities in the old areas of the Old City probably are a good thing for the fragile historic fabric of this city. It is possible that it is due to low movement densities the processes of change have remained slow here. However, one needs to be careful not to overstretch the point, because a lack of movement can harm the economic vitality of a city. Therefore, the lesson heritage planners should take from the Old City of Jeddah is that movement densities in relatively fragile areas of a historic city should be kept low as long as they do not become impediments to economic viability.

With regards to the relationships between spatial configuration and movement densities, the study reported that the spatial configuration of the Old City of Jeddah was a big factor in the way movement densities of people and cars were distributed in the city. For example, while densities of cars were more strongly associated with the syntactic variables than that of people in the major streets of the Old City, densities of people were more strongly associated with syntactic variables than that of cars in the secondary streets of the Old City. Compared to the primary and secondary streets, local streets showed fewer correlations with movement densities indicating that movement densities in these streets might still be dependent on socio-cultural and religious norms of the Old City. The lesson here for heritage planners is that they must take into account the fact that spatial configuration can be an important force shaping urban life in different types of streets in a historic city, and that spatial configuration affects movement densities of people and cars on different streets in different ways. While many historic cities put in place 'active' regulatory mechanisms to control movement densities, the effectiveness of these mechanisms 
often depend on appropriate spatial controls. As this and many other previous space syntax studies have shown, spatial configuration can be a very effective 'passive' means for controlling movement patterns. Spatial configuration is a passive means to control movement patterns because often its effects remain unnoticed. This brings us to the last but the most important finding reported in this study regarding the heritage planning of historic cities.

With regards to the spatial configuration of the Old City of Jeddah, the study reported that the Old City was well integrated syntactically as an independent system, but that it was also somewhat independent syntactically from the larger system within which it is now embedded. The syntactic independence of the spatial configuration of the Old City from the larger system might have played a positive role in restricting through-movements. As a result, it might have prevented the Old City from higher movement densities and from functions that follow higher densities of through-movements. Similarly, the syntactic integrity of the configuration might have also played a positive role in distributing to-movements within the Old City ensuring vitality and a sense unity that it still possesses even though it has lost its physical identity as a walled city and has since then become a part of a much larger city. The lesson here for heritage planners is that they should treat a historic city not only as a static physical artifact to be preserved but also as a network or configuration of spaces that brings in life and dynamic unity through movements and function s that follow.

Despite the relevance the findings of this study to the heritage planning of the Old City of Jeddah and of other historic cities, it should be noted here that the relationships between space and movement of people and cars are only one of many features of the camaraderie of a traditional historic city in Islamic societies. Attempts to define these features of the traditional historic city in Islamic societies have been a subject of an on-going debate. For example, in order to 
understand the traditional historic cities in Islamic societies, some scholars studied social spaces of neighborhoods in relation to gender segregation and the decentralized body of Islamic legal traditions (Abu-Lughod, 1993; Hakim 1986, Lapidus, 1969). Other scholars studied symbolic representations and the production of meaning, as opposed to structural processes and institutions, to argue that there are clear Islamic influences on urban form and spaces in Islamic societies (Ardalan and Bakhtiar 1973; Noe, 1993; Saqqaf 1987). Yet others studied property ownership and control to understand the traditional cities in Islamic societies (Akbar, 1988).

It is possible that the absence of an integrated and comprehensive understanding of the traditional historic cities in Islamic societies in terms of mental, physical, and social space, as the kind proposed by Henri Lefebvre (1974/1992), has made the work of a heritage planner more difficult. Therefore, what must occupy the central stage in future studies of these cities is to establish the linkages between these different kinds of spaces. If any heritage planning of historic cities in Islamic societies ought to succeed, it would have to focus, at the least, on the very meaning of the relationship between space and movement, of the kinds studied here, in relation to social and symbolic realities of Islamic societies. 


\section{REFERENCES}

Abu-Lughod, J. (1993) The Islamic City: Historic Myth, Islamic Essence, and Contemporary Relevance. In H. Amirahmadi and S. S. El-Shakhs (eds.) Urban development in the Muslim world. New Brunswick, New Jersey: The Center for Urban Policy Research, pp. 11-36.

Akbar, J. (1988) Crisis in the built environment: the case of the Muslim city. New York: EJ Brill. Alberts, H. C. and Hazen, H. D. (2010) Maintaining authenticity and integrity at cultural World Heritage Sites. The Geographical Review 100(1): 56-73.

Alexander, C. (1966) The city is not a tree. Design 206: 46-55.

Amirahmadi, H. and El-Shakhs, S. S. (eds.) (1993) Urban development in the Muslim world. New Brunswick, New Jersey: The Center for Urban Policy Research.

Ardalan, N. and Bakhtiar, L. (1973) The sense of unity. Chicago: University of Chicago Press.

Ashworth, G. J. (1993) Heritage planning: an approach to managing historic cities. In Z. Zuziak (ed.) Managing Historic Cities. Cracow: International Cultural Center, pp. 27-47.

Baer, W. (1995) The Conservation and Use of the Walled City of Tripoli. Geographical Journal 160(2): 143-148.

Baran, P. K., Rodríguez, D. A., and Khattak, A. J. (2008) Space Syntax and walking in a new urbanist and suburban neighborhoods. Journal of Urban Design 13(1): 5-28.

Buchanan, P. (1988) What city? A plea for place in the public realm. Architectural Review 1101: $31-41$.

Byrne, D. (1991). Western Hegemony in Archaeological Heritage Management. History and Anthropology 5: 269-76.

Castells, M. (2002) Local and global: cities in the network society. Tijdschrift voor Economische en Sociale Geografie 93: 548-58.

Christaller, W. (1966) Central Places in Southern Germany, C. W. Baskin (trans.). London: Prentice-Hall. [Original in Germany 1933]

Cook, R. (1980). Zoning for Downtown Urban Design. New York, NY: Lexington Books.

Ford, L. (1985) Urban Morphology and Preservation in Spain. Geographical Review 75(3): 265299.

Gehl, J. (1989). A changing street life in a changing society. Places (Fall): 8-17. 
Goffman, E. (1963) Behavior in public places: Notes on the social organization of gatherings. New York, NY: Free Press.

Goffman, E. (1972) Relations in public: Micro studies of the public order. New York, NY: Harper \& Row.

Hakim, B. S. (1986) Arabic-Islamic cities: building and planning principles. London: KPI.

Hesse, M. (2010) Cities, material flows and the geography of spatial interaction: urban places in the system of chains. Global Networks 10(1): 75-91.

Hillier, B. (2008). Space and spatiality: what the built environment needs from social theory. Building Research \& Information 36(3): 216-230.

Hillier, B. (2005). The art of place and the science of space. World Architecture - Special Issue on Space Syntax 11: 96-102.

Hillier, B. (1996) Space is the Machine. Cambridge: Cambridge University Press.

Hillier, B. and Hanson, J. (1984) The Social Logic of Space. Cambridge: Cambridge University Press.

Hillier, B. and Iida, S. (2005) Network effects and psychological effects: a theory of urban movement. In A van Nes (ed.) Proceedings of the 5th International Symposium on Space Syntax Volume I. Delft, Netherlands: TU Delft, pp. 553-564.

Hillier, B., Penn, A., Hanson, J., Grajewski, T., and Xu J. (1993) Natural movement; or, configuration and attraction in urban pedestrian movement. Environment and Planning B: Planning and Design 20: 29-66.

IBM Corp. (Released 2011) IBM SPSS Statistics for Windows, Version 20.0. Armonk, NY: IBM Corp.

ICOMOS (1964) The Venice Charter: International Charter for the Conservation and Restoration of Monuments and Sites. Second International Congress of Architects and Technicians of Historic Monuments, Venice, Italy, 1964 [accessed 20 June 2010]. Available at: <www.icomos.org/venice_charter.html>

Jacobs, J. (1961) The Death and Life of Great American Cities. New York, NY: Random House. Jensen, O. B. (2010) Negotiation in motion: unpacking a geography of mobility. Space and Culture 13: 389-403.

Lapidus, I. M. (1969) Middle Eastern cities: a symposium on ancient, Islamic, and contemporary Middle Eastern urbanism. Berkeley, CA: University of California Press. 
League of Nations, 1931 Athens Charter for the Restoration of Historic Monuments. Adopted at the First International Congress of Architects and Technicians of Historic Monuments, Athens 1931 [accessed 12 January 2010]. Available at: <www.icomos.org/anthens_charter.html>

Lefebvre, H. (1991) The Production of Space, D. Nicholson-Smith (trans.). Oxford: Blackwell. [Original in French 1974]

Lowenthal, D. (1995) Changing Criteria for Authenticity. In K. E. Larsen (ed.) Nara Conference on Authenticity in Relation to the World Heritage Convention, Nara, Japan, 1-6 November 1994. Paris: UNESCO World Heritage Centre, pp. 121-36.

Montgomery, J. (1998). Making a City: Urbanity, Vitality and Urban Design. Journal of Urban Design 3 (1): 93-116.

Noe, S. V. (1993) The Walled City of Delhi: Retrospect and Prospect in Urban development in the Muslim world. In H. Amirahmadi and S. S. El-Shakhs (eds.) Urban development in the Muslim world. New Brunswick, New Jersey: The Center for Urban Policy Research, pp. 72-93.

Pendlebury, J., Short, M., and While, A. (2009) Urban World Heritage Sites and the problem of authenticity. Cities 26: 349-358.

Peponis, J., Hadjinikolaou, E., Livieratos, C., and Fatouros, D. A. (1989) The spatial core of urban culture. Ekistics 334-335: 43-55.

Peponis. J., Ross, C., and Rashid, M. (1997) The structure of urban space, movement and copresence: the case of Atlanta. Geoforum 28(3-4): 341-358.

Poulios, I. (2010) Moving beyond a values-based approach to heritage conservation. Conservation and Mgmt of Arch. Sites 12(2): 170-85.

Rodwell, D. (2007) Conservation and Sustainability in Historic Cities. Oxford: Blackwell.

Rodwell, D. (2008) Urban regeneration and the management of change: Liverpool and the historic urban landscape. Journal of Architectural Conservation 14(2): 83-106.

Saqqaf, A. Y. (ed.) (1987) The Middle East city: ancient traditions confront a modern world 2 nd edition. New York: Paragon House Publishers.

Turner. A., and Friedrich, E. (2010-11) Depthmap software, version 10.14.00b. London: University College London.

UNESCO (2005) Vienna Memorandum on "World Heritage and Contemporary ArchitectureManaging the Historic Urban Landscape.” Paris: World Heritage Centre, p. 6. [accessed 28 April 2013]. Available at: 〈http://whc.unesco.org/en/activities/48>. 
Ullman, E. L. (1980) Geography as spatial interaction. In E. L. Ullman and R. R. Boyce (eds.) Geography as spatial interaction. Seattle: University of Washington Press, pp. 13-27. [Original in 1954]

Weber. M. (1968) Economy and Society, G. Roth and C. Wittich (eds.). New York, NY: Bedminster Press Incorporated. [Original in Germany 1921]

Zubaida, S. (1989) Islam, the people and the state. London and New York: Routledge. 